\title{
Correction to: Gravity reference at the Argentinean-German Geodetic Observatory (AGGO) by co-location of superconducting and absolute gravity measurements
}

\author{
Ezequiel D. Antokoletz ${ }^{1,4}\left(\mathbb{D} \cdot\right.$ Hartmut Wziontek $^{2} \cdot$ Claudia N. Tocho $^{1} \cdot$ Reinhard Falk $^{3}$
}

Published online: 9 December 2020

(c) The Author(s) 2020

\section{Correction to: \\ Journal of Geodesy (2020) 94:81 https://doi.org/10.1007/s00190-020-01402-7}

The article "Gravity reference at the Argentinean-German Geodetic Observatory (AGGO) by co-location of superconducting and absolute gravity measurements", written by Ezequiel D. Antokoletz, Hartmut Wziontek, Claudia N. Tocho, Reinhard Falk, was originally published Online First without Open Access. After publication in volume 94, issue 9, page 1-9 the author decided to opt for Open Choice and to make the article an Open Access publication. Therefore, the copyright of the article has been changed to (C) The Author(s) 2020 and the article is forthwith distributed under the terms of the Creative Commons Attribution 4.0 International License, which permits use, sharing, adaptation, distribution and reproduction in any medium or format, as long as you give appropriate credit to the original author(s) and the source, provide a link to the Creative Commons licence, and indicate if changes were made. The images or other third party material in this article are included in the article's Creative Commons licence, unless indicated otherwise in a credit line to the material. If material is not included

The original article can be found online at https://doi.org/10.1007/s00 190-020-01402-7.

Ezequiel D. Antokoletz

eantokoletz@fcaglp.unlp.edu.ar

1 Facultad de Ciencias Astronómicas y Geofísicas, Universidad Nacional de La Plata, Paseo del Bosque s/n, La Plata, Argentina

2 Gravity Metrology, Federal Agency for Cartography and Geodesy (BKG), Karl-Rothe-Straße 10, Leipzig, Germany

3 Gravity Metrology, Federal Agency for Cartography and Geodesy (BKG), Richard-Strauss-Allee 11, Frankfurt am Main, Germany

$4 \quad$ National Scientific and Technical Research Council (CONICET), Buenos Aires, Argentina in the article's Creative Commons licence and your intended use is not permitted by statutory regulation or exceeds the permitted use, you will need to obtain permission directly from the copyright holder. To view a copy of this licence, visit http://creativecommons.org/licenses/by/4.0/.

The original article has been updated.

Open Access This article is licensed under a Creative Commons Attribution 4.0 International License, which permits use, sharing, adaptation, distribution and reproduction in any medium or format, as long as you give appropriate credit to the original author(s) and the source, provide a link to the Creative Commons licence, and indicate if changes were made. The images or other third party material in this article are included in the article's Creative Commons licence, unless indicated otherwise in a credit line to the material. If material is not included in the article's Creative Commons licence and your intended use is not permitted by statutory regulation or exceeds the permitted use, you will need to obtain permission directly from the copyright holder. To view a copy of this licence, visit http://creativecommons.org/licenses/by/4.0/.

Acknowledgement The authors sincerely thank the Federal Agency for Cartography and Geodesy (BKG) for supporting the Open Access Option. 